\title{
Bekam efektif menurunkan tekanan darah pada pertengahan Bulan Hijriyah
}

\author{
Cupping effectively reduces blood pressure in Mid-Hijriyah \\ Hani Fauziah, ${ }^{1, *}$, Yani Sofiani², Diana Irawati ${ }^{3}$ \\ ${ }^{1,2,3}$ Universitas Muhammadiyah Jakarta, Jalan K. H. Ahmad Dahlan Cirendeu Ciputat Jakarta 15419, Indonesia \\ ${ }^{1}$ fauziah.hani@ymail.com*; ${ }^{2}$ yani_sofiani@umj.ac.id; ${ }^{3}$ diana.irawati80@gmail.com \\ ${ }^{1}$ fauziah.hani@ymail.com* \\ * corresponding author
}

Tanggal Submisi: 26 Agustus 2019, Tanggal Penerimaan: 10 Oktober 2019

\begin{abstract}
Abstrak
Bekam adalah pengobatan yang disunnahkan oleh Rosulullah SAW yang dapat mengatasi hipertensi. Bahkan dalam haditsnya disebutkan keutamaan waktu berbekam pada bulan Hijriyah. Penelitian bertujuan untuk mengetahui efektifitas bekam yang dilakukan pada pertengahan bulan hijriyah terhadap penurunan tekanan darah. Desain yang digunakan quasi eksperimen pre dan post test dengan sampel 51 responden, yang terbagi menjadi tiga kelompok berdasarkan waktu berbekam pada awal, pertengahan dan akhir bulan hijriyah. Hasilnya adanya pengaruh signifikan penurunan tekanan darah pada semua kelompok dengan nilai rerata tertinggi ada pada kelompok tengah, sehingga dapat disimpulkan bekam lebih efektif dilakukan pada pertengahan bulan hijriyah untuk menurunkan tekanan darah.
\end{abstract}

Kata Kunci: bekam; tekanan darah; pertengahan bulan hijriyah

\begin{abstract}
Cupping is a treatment that is blessed by Rosulullah SAW that can overcome hypertension. Even in his hadith it is mentioned the virtue of when it records in the month of Hijriyah. The study aims to determine the effectiveness of cupping conducted in the middle of the Islamic month to reduce blood pressure. The design used was quasi pre and post test experiments with a sample of 51 respondents, which were divided into three groups based on the time of recording at the beginning, middle and end of the Islamic month. The result is a significant influence in reducing blood pressure in all groups with the highest mean values in the middle group, so it can be concluded that cupping is more effective in the middle of the Islamic month to reduce blood pressure.
\end{abstract}

Keywords: cupping therapy; blood pressure, mid hijriyah

\section{PENDAHULUAN}

Hipertensi yang dikenal dengan istilah silent killer merupakan faktor risiko utama terjadinya penyakit kardiovaskular yang dapat mengancam jiwa yang banyak ditemui di seluruh dunia, tidak terkecuali di Indonesia. Data yang didapatkan dari Riset Kesehatan Dasar (Riskesdas) tahun 2013 tercatat jumlah penderita hipertensi sebesar 
25,8\%. Angka ini mengalami peningkatan pada tahun 2018 menjadi 34,1\% jumlah penduduk Indonesia yang menderita hipertensi (Riskesdas, 2018).

Peningkatan tekanan darah dalam jangka waktu lama (persisten) dan tidak mendapatkan penanganan yang memadai dapat menimbulkan berbagai komplikasi serius pada organ tubuh dan dapat menyebabkan kematian. Berbagai upaya dilakukan untuk mengatasi hipertensi salah satunya dengan terapi komplementer. $\mathrm{Hu}, \mathrm{Li}$, Duan dan Arao (2013) memaparkan tentang jenis-jenis terapi alternatif komplementer yang dipilih oleh penderita hipertensi diantaranya yaitu alternative medical system (pengobatan tradisional China, akupuntur dan bekam). Terapi bekam dikenal sebagai salah satu metode pengobatan tertua yang dikenal di banyak negara dan peradaban, terutama di Asia dan Eropa (Kordafshari, Ardakani, Keshavarz, Esfahani, Nazeem, et all, 2017).

Terapi bekam memiliki banyak keutamaan dalam pandangan Islam. Keutamaan ini diungkapkan oleh Rosulullah SAW dalam salah satu haditsnya yang artinya "Sesunggguhnya pengobatan paling iseal yang kalian gunakan adalah hijamah (bekam) dan qustul bahri" (H.R Bukhori 5371 dan Muslim 1577). Selain itu Rosulullah SAW juga mengungkapkan keutamaan waktu dalam berbekam, sebagaimana haditsnya "Barang siapa meminta bekam pada tanggal 17, 19 dan 21 makan akan terjadi kesembuhan dari segala penyakit” (H.R Hakin dan Abu Dawud dan Al-Baihaqy) (Rahmadi, 2019). Hal ini membuat peneliti merasa tertarik untuk melihat efektifitas waktu berbekam dengan tekanan darah.

\section{METODE PENELITIAN}

Desain yang digunakan quasi experimen pre and post test non control group dengan sampel 51 responden yang menderita hipertensi. Responden dibagi dalam tiga kelompok berdasarkan waktu berbekam, yaitu kelompok yang di bekam pada awal bulan hijriyah setiap tanggal 1-14, kelompok tengah (tanggal 15-21) dan kelompok akhir (tanggal 22-29 atau 30). Setiap kelompok terdiri dari 17 responden. Pengambilan sampel dilakukan dengan consecutive sampling, dengan menjunjung tinggi prinsip etika penelitian.

Pengambilan data dilakukan dengan mengobservasi hasil pengukuran tekanan darah sebelum dan sesudah dilakukan terapi bekam pada semua kelompok responden. Data tekanan darah sistolik (TDS) dan diastolik (TDD) yang telah terkumpul selanjutnya di olah dengan menggunakan program SPSS dan dilanjutkan dengan proses analisis data menggunakan uji paired T-test.

\section{HASIL DAN PEMBAHASAN}

Analisi univariat pada penelitian ini memaparkan karakteristik responden pada tiga kelompok berdasarkan usia, jenis kelamin, tingkat pendidikan, indeks massa tubuh, riwayat hipertensi dan riwayat bekam.

\section{Usia}

Tabel 1. Distribusi responden berdasarkan usia

\begin{tabular}{cccc}
\hline \multirow{2}{*}{ Variabel } & Klp awal (n=17) & Klp tengah (n=17) & Klp akhir (n=17) \\
\cline { 2 - 4 } & Rata-rata \pm SD (min-maks) & Rata-rata \pm SD (min-maks) & Rata-rata \pm SD (min-maks) \\
\hline Usia & $49,65 \pm 10,88(22-68)$ & $46,82 \pm 10,56(25-60)$ & $47,29 \pm 10,69(29-65)$ \\
\hline
\end{tabular}

Tabel 1 menunjukkan bahwa usia responden yang menderita hipertensi pada ketiga kelompok tidak jauh berbeda yaitu berada pada rentang usia mulai dari 46,82 sampai usia 49,65 tahun. Black dan Hawks (2014) menjelaskan bahwa hipertensi primer 
biasanya mulai muncul antara rentang usia 30-50 tahun. Pertambahan usia dapat menyebabkan terjadinya penurunan elastisitas dinding pembuluh darah arteri dan digantikan oleh jaringan fibrosis yang tidak dapat meregang dengan baik sehingga resistensi terhadap aliran darah semakin besar. Resistensi perifer adalah besarnya hambatan terhadap aliran darah yang ditentukan oleh tonus otot pembuluh darah dan diameternya. Semakin kecil ukuran lumen pembuluh darah perifer, maka semakin besar resistensinya terhadap aliran darah. Hal ini menyebabkan tekanan pada dinding pembuluh darah arteri meningkat sehingga tekanan darah meningkat (Potter \& Perry, 2010).

Hasil penelitian ini yang sejalan dengan penelitian yang dilakukan oleh Irawan dan Ari (2012), Akbar dan Mahati (2013), Safrianda (2015), Fatonah, Irihantoro dan Astuti (2015) yang memaparkan bahwa rerata rentang usia responden hipertensi yang menjalani terapi bekam yaitu di atas usia 40 tahun.

\section{Jenis kelamin, Tingkat Pendidikan, IMT, Riwayat Hipertensi dan Riwayat Bekam}

Karakteristik responden selain usia yang digambarkan pada penelitian ini yaitu jenis kelamin, tingkat pendidikan, indeks massa tubuh, riwayat hipertensi dan riwayat bekam yang dapat dilihat pada tabel 2 dibawah ini:

Tabel 2. Distribusi responden berdasarkan jenis kelamin, tingkat pendidikan, IMT, riwayat hipertensi dan riwayat bekam

\begin{tabular}{lccc}
\hline \multicolumn{1}{c}{ Variabel } & $\begin{array}{c}\text { Klp awal (n=17) } \\
\mathbf{f}(\mathbf{\%})\end{array}$ & $\begin{array}{c}\text { Klp tengah (n=17) } \\
\mathbf{f}(\mathbf{\%})\end{array}$ & $\begin{array}{c}\text { Klp akhir (n=17) } \\
\mathbf{f}(\mathbf{\%})\end{array}$ \\
\hline Jenis kelamin & & & \\
Laki-laki & $13(76,5)$ & $13(76,5)$ & $11(64,7)$ \\
Perempuan & $4(23,5)$ & $4(23,5)$ & $6(35,5)$ \\
\hline Tingkat Pendidikan & & & \\
SD & 0 & $1(5,9)$ & 0 \\
SMP & $2(11,8)$ & $6(35,3)$ & $1(5,9)$ \\
SMA & $3(15,6)$ & $6(35,3)$ & $12(70,6)$ \\
PT & $12(70,6)$ & $4(23,5)$ & $4(23,5)$ \\
\hline IMT & & & 0 \\
Sangat Kurus & 0 & $1(5,9)$ & $1(5,9)$ \\
Kurus & 0 & 0 & $3(17,6)$ \\
Normal & $3(17,6)$ & $3(13,6)$ & $3(17,6)$ \\
BB Lebih & $3(17,6)$ & 0 & $10(58,8)$ \\
Obesitas & $11(64,7)$ & $13(76,5)$ & $9(52,9)$ \\
\hline Riwayat Bekam & $1(5,9)$ & & $8(47,1)$ \\
Pertama & $16(94,1)$ & $3(17,6)$ & \\
$>$ sekali & & $14(82,4)$ & $9(17,6)$ \\
\hline Riwayat Hipertensi & $5(29,4)$ & $3(17,6)$ & $8(47,1)$ \\
< setahun & $12(70,6)$ & $14(82,4)$ & \\
$>$ setahun & & &
\end{tabular}

\section{Jenis Kelamin}

Jenis kelamin responden pada ketiga kelompok dalam penelitian ini di dominasi oleh laki-laki dengan prosentase diatas $60 \%$. Hal ini menunjukkan bahwa laki-laki lebih rentan menderita hipertensi dibandingkan dengan perempuan. Jenis kelamin juga merupakan salah satu faktor risiko hipertensi yang tidak dapat di ubah, pada keseluruhan insiden hipertensi lebih banyak terjadi pada laki-laki dibandingkan pada wanita. Hal ini biasanya dikaitkan dengan gaya hidup yang tidak sehat seperti merokok, 
konsumsi minuman beralkohol, menggunakan zat adiktif dan juga mudah mengalami stress (Black \& Hawks, 2014). Hal senada juga dipaparkan oleh Potter dan Perry (2010), bahwa setelah pubertas laki-laki cenderung memiliki tekanan darah yang lebih tinggi dibandingkan perempuan.

Hal ini senada dengan penelitian yang dilakukan oleh Thamrin (2012), serta penelitian Akbar dan Mahati (2013) yang memaparkan bahwa jumlah responden lakilaki penderita hipertensi yang melakukan terapi bekam lebih banyak dibanding responden perempuan. Hal yang menyebabkan perempuan lebih jarang di bekam yaitu rasa takut sakit saat dilakukan perlukaan kulit untuk proses penghisapan darah, selain itu juga kawatir bekas perlukaan pada kulit akan lama sembuh.

\section{Tingkat Pendidikan}

Tingkat pendidikan responden bervariasi mulai dari tingkat pendidikan sekolah dasar (SD) sampai dengan tingkat perguruan tinggi (PT). Pada kelompok awal didominasi oleh responden dengan tingkat pendidikan PT dengan prosentase $70,6 \%$ dan pada kelompok tengah tingkat pendidikan paling banyak yaitu SMP dan SMA dengan prosentase $35,3 \%$ sedangkan pada kelompok akhir tingkat pendidikan responden paling banyak yaitu SMA dengan prosetase 70,6\%. Tingkat pendidikan responden pada ketiga kelompok bervariasi mulai dari tingkat sekolah dasar (SD) sampai tingkat perguruan tinggi (PT). Hal ini juga senada dengan penelitian yang dilakukan oleh Damayanti, Muharini, dan Gunawan (2012) dan penelitian Safrianda (2015) yang memaparkan bahwa pengobatan bekam digunakan oleh masyarakat dengan pendidikan bervariasi, yakni mulai lulusan SMP sampai lulusan perguruan tinggi. Semakin tinggi tingkat pendidikan seseorang, maka cenderung lebih peduli terhadap kesehatan terutama terkait pencegahan dan lebih mudah memperoleh informasi tentang kesehatan melalui akses teknologi.

\section{Indeks Massa Tubuh}

Pada tiga kelompok terlihat bahwa rata-rata responden masuk dalam kategori obesitas dengan prosentase lebih dari $60 \%$. Obesitas merupakan salah satu faktor risiko terjadinya hipertensi. Penumpukan lemak dalam darah menyebabkan banyaknya timbunan plak (aterosklerosis) pada dinding pembuluh darah sehingga terjadi penempitan lumen. Hal ini menyebabkan resistensi terhadap aliran darah semakin besar, akibatnya saat ventrikel kiri berkontraksi maka pembuluh darah tersebut tidak mampu menyesuaikan diri terhadap tekanan. Volume yang dipompakan tersebut akan melewati dinding pembuluh darah yang kaku sehingga terjadi peningkatan tekanan sistemik (Potter \& Perry, 2010).

\section{Riwayat Hipertensi}

Hasil penelitian ini menggambarkan bahwa responden pada kelompok awal memiliki riwayat hipertensi lebih dari setahun dengan prosentase $70,6 \%$ dan $82,4 \%$ sedangkan pada kelompok akhir 52,9\% memiliki riwayat hipertensi kurang dari setahun. Hal ini juga senada dengan hasil penelitian yang dilakukan oleh Lestari, Hartanto dan Susanti (2017), yang menyebutkan bahwa ada 92,9\% responden memiliki riwayat hipertensi 1-5 tahun.

\section{Riwayat Bekam}

Responden pada tiga kelompok yang diteliti sudah mempunyai riwayat bekam lebih dari satu kali, dengan rerata prosentase $82,4 \%$ sampai 94,1\%. Berdasarkan hasil wawancara yang dilakukan pada beberapa responden disebutkan bahwa mereka merasa cocok dengan bekam, badan terasa ringan dan keluhan sakit kepala berkurang setelah di bekam. Hasil penelitian Thamrin (2012) juga memaparkan bahwa responden yang 
mempunyai pengalaman berbekam lebih dari sekali yaitu sebanyak 53,12\%. Senada dengan Safrianda (2015) bahwa $62,5 \%$ responden memiliki pengalaman berbekam lebih dari satu kali. Hal ini menunjukkan bahwa terapi bekam cukup diminati oleh masyarakat sebagai salah satu pengobatan komplementer yang dapat meningkatkan kesehatan dirinya.

Nurdiyana, dkk (2010) dalam penelitiannya menjelaskan bahwa ada tiga motivasi yang menyebabkan seseorang memilih terapi bekam, yaitu pertama motivasi biogenetis dimana seseorang memilih bekam sekedar untuk menyembuhkan penyakitnya, kedua motivasi sosiogenetis yaitu pasien memilih terapi bekam karena pengaruh lingkungan disebabkan ajakan, testimoni atau sugesti orang terdekat yang terakhir yaitu motivasi teogenetis, yaitu seseorang yang menjalankan terapi bekam karena norma agama khususnya untuk yang beragama Islam.

\section{Analisis Bivariat}

Analisis bivariat pada penelitian ini dilakukan untuk melihat efektifitas perubahan tekanan darah sistolik (TDS) dan diastolik (TDD) sebelum dan sesudah dilakukan terapi bekam pada tiga kelompok responden. Peneliti menggunakan uji paired $T$ test untuk setiap kelompok, pemilihan uji ini dilakukan setelah sebelumnya dilakukan uji normalitas data dengan nilai rata-rata shapiro-wilk pada semua kelompok $>0,05$. Hasil uji statistik pada setiap kelompok dapat dilihat pada tabel 3.

Tabel 3. Distribusi rerata nilai TDS, TDD dan hasil uji paired $T$ test sebelum dan sesudah terapi bekam pada semua kelompok responden

\begin{tabular}{lcccc}
\hline \multicolumn{1}{c}{ Variabel } & Mean & Selisih mean & SD & P value \\
\hline Klp Awal & & & & \\
TDS Sebelum & 157,53 & 13,58 & 9,906 & 0,0001 \\
$\begin{array}{l}\text { TDD Sesudah } \\
\text { TDD sebelum }\end{array}$ & 143,94 & & & \\
TDD Sesudah & 100,71 & 8,58 & 6,124 & 0,0001 \\
\hline Klp Tengah & 92,12 & & & \\
TDS Sebelum & 160,24 & 20,24 & 12,03 & 0,0001 \\
$\begin{array}{l}\text { TDD Sesudah } \\
\text { TDD sebelum }\end{array}$ & 140,00 & & & \\
TDD Sesudah & 102,53 & 10,00 & 5,23 & 0,0001 \\
\hline Klp Akhir & 92,53 & & & \\
TDS Sebelum & 152,53 & 11,65 & 7,37 & 0,001 \\
TDD Sesudah & 140,88 & & & \\
TDD sebelum & 97,24 & 6,71 & 2,24 & 0,002 \\
TDD Sesudah & 90,53 & & & \\
\hline
\end{tabular}

\section{Analisis Pengaruh Bekam terhadap Penurunan Tekanan Darah}

Hasil analisis data menunjukan adanya penurunan tekanan darah sistolik (TDS) dan diastolik (TDD) sebelum dan sesudah dilakukan terapi bekam pada semua kelompok. Rerata penurunan nilai TDS berkisar $11,65 \mathrm{mmHg}$ sampai 20,24 mmHg. Sedangkan rerata untuk TDD berkisar antara $6,71 \mathrm{mmHg}$ sampai $10,00 \mathrm{mmHg}$. Hasil uji paired T test untuk semua kelompok responden diperoleh angka $\mathrm{P}$ value sebesar $<$ 0,0001. Hal ini menunjukan bahwa hipotesis nol (Ho) di tolak, artinya terdapat perbedaan yang signifikan nilai TDS dan TDD sebelum dan sesudah dilakukan terapi bekam pada semua kelompok responden.

Hasil penelitian ini sejalan dengan penelitian yang dilakukan oleh Irawan dan Ari (2010), Safrianda (2015), penelitian oleh Departemen Kesehatan di Rumah Sakit Universitas King Abdulaziz, Jeddah Saudi Arabia tahun 2016 dan penelitian lainnya 
oleh Akbar dan Mahati (2017) yang menunjukan adanya pengaruh terapi bekam yang signifikan terhadap penurunan nilai tekanan darah sistolik dan diastolik.

Penurunan tekanan darah sistolik dan diastolik setelah dilakukan terapi bekam disebabkan adanya proses pengekopan (penghisapan area kulit dan subkutis) dan perlukaan jaringan kulit yang menyebabkan kerusakan sel mast di area tersebut. Kerusakan ini menstimulasi pengeluaran mediator kimiawi seperti serotonin, histamin, bradikinin, slow reacting substance (SRS), serta zat-zat lainnya yang menyebabkan terjadinya vasodilatasi pembuluh darah kapiler dan arteriol, serta flare reaction pada daerah yang dibekam. Dilatasi kapiler juga dapat terjadi di tempat yang jauh dari lokasi pembekaman. Hal ini menyebabkan terjadinya perbaikan mikrosirkulasi pembuluh darah. Akibatnya akan timbul efek relaksasi otot-otot yang kaku serta akibat vasodilatasi secara umum akan menurunkan tekanan darah secara stabil (Umar, 2012).

Hal senada juga dijelaskan oleh Sherwood (2016) bahwa kerusakan jaringan akan menstimulasi pelepasan histamin. Histamin adalah mediator kimiawi lokal yang mempengaruhi otot polos arteriol. Pengeluaran histamin berdampak pada peningkatan permeabilitas kapiler dengan memperbesar pori kapiler (celah antara sel-sel endotel) serta vasodilatasi arteriol di area yang mengalami kerusakan. Selain karena pengaruh histamin, dilatasi pembuluh darah arteriol juga terjadi karena sel endotel melepaskan nitrit okside (NO) yang berdifusi ke otot polos dibawahnya dan memicu terjadinya vasodilatasi. Saat dilakukan penghisapan darah akan menstimulasi saraf-saraf sensorik pada kulit, rangsangan ini dilanjutkan pada cornu posterior medulla spinalis melalui saraf A delta dan $\mathrm{C}$, serta traktus spino thalmikus ke arah thalamus yang akan menghasilkan endorphin. Pengeluaran endorphin akan berdampak pada suasana hati yang senang dan tenang, yang menyebabkan perasaan rileks dan denyut jantung akan menurun. Hal ini menyebabkan tekanan darah juga mengalami penurunan (Rahmadi, 2019).

Hasil penelitian ini diperkuat dengan penelitian yang dilakukan oleh Akbar dan Mahati (2013) serta Lestari, Hartono, Susanti (2017) yang menunjukan adanya perubahan nilai TDS dan TDD sebelum dan sesudah bekam pada penderita hipertensi.

\section{Efektifitas Perbedaan Selisih Rerata Nilai Tekanan Darah Sistolik dan Diastolik Antara Tiga Kelompok Responden}

Analisis selisih nilai rerata TDS dan TDD dari tiga kelompok responden terlihat bahwa penurunan tekanan darah sistolik dan diastolik pada kelompok responden yang dilakukan terapi bekam pada pertengahan bulan hijriyah lebih besar nilainya dibandingkan dengan kelompok responden yang di bekam pada awal dan akhir bulan hijriyah, dengan rerata penurunan tekanan darah tertinggi ada pada kelompok tengah dengan nilai TDS sebesar 20,24 $\mathrm{mmHg}$ dan TDD 10,00 $\mathrm{mmHg}$.

Pembekaman yang dilakukan pada pertengahan bulan hijriyah yaitu antara tanggal 15- 21 setiap bulannya, bertepatan dengan posisi bulan yang tegak lurus terhadap bumi. Ibnu Sina dalam kitabnya Al-Qonun dalam Fatah (2004) menjelaskan bahwa waktu terbaik untuk berbekam adalah satu minggu dipertengahan bulan-bulan Qomariyah, yaitu satu minggu setelah purnama karena pada waktu ini gaya gravitasi bulan sedang maksimal terhadap bumi. Hal ini menyebabkan darah tertarik ke area permukaan kulit sehingga pada waktu ini akan maksimal dan efektif untuk pengeluaran darah statis, dan toksin dalam darah dan memperlancar aliran darah.

Sebagaimana diketahui bahwa gravitasi dapat mempengaruhi tubuh manusia yang hidup diatas permukaan bumi. Gravitasi didefinisikan sebagai gaya tarik menarik yang terjadi antara semua partikel yang mempunyai massa di alam semesta. Salah satu 
contohnya yaitu bumi. Bumi memiliki massa yang sangat besar akan menghasilkan gaya gravitasi yang sangat besar untuk menarik benda-benda yang ada disekitarnya termasuk makhluk hidup dan benda-benda yang ada di bumi (Abdullah, 2016).

Teori Newton mengungkapkan bahwa tiap-tiap benda di alam semesta akan melakukan gaya tarik menarik. Besarnya gaya ini berbanding lurus dengan perkalian massa kedua benda tersebut dan berbanding terbalik dengan kuadrat jarak antar dua benda tersebut. Gaya gravitasi inilah yang mengikat planet-planet sehingga tetap berada di sistem tata surya meskipun planet-planet tersebut selalu bergerak. Arah gaya gravitasi sejajar dengan garis hubung kedua benda tersebut (Abdullah, 2006).

Schmidt (2013) dalam peneltiannya yang berjudul Pengaruh Gravitasi pada Tubuh Manusia menjelaskan bahwa gaya gravitasi dapat berpengaruh terhadap fungsi organ tubuh terutama jantung dan aliran pada pembuluh darah. Potter dan Perry (2010) menjelaskan bahwa tekanan darah dapat dipengaruhi oleh curah jantung, resistensi perifer, volume darah dan viskositas darah.

\section{SIMPULAN}

Hasil penelitian ini dapat disimpulkan bahwa bekam yang dilakukan pada pertengahan bulan hijriyah dapat menurunkan tekanan darah lebih efektif dibandingkan jika dilakukan pada awal atau akhir bulan hijriyah dengan nilai rerata penurunan nilai tekanan darah sistolik (TDS) sampai 20,24 $\mathrm{mmHg}$ dan tekanan darah diastolik (TDD) sampai $10,00 \mathrm{mmHg}$.

\section{SARAN}

Terapi bekam dapat dijadikan salah pilihan terapi non farmakologis alternatif untuk membantu menurunkan tekanan darah sistolik dan diastolik pada pasien hipertensi. Selain itu juga hasil penelitian ini diharapkan dapat dijadikan pengembangan ilmu pengetahuan khususnya dibidang keperawatan untuk membantu menurunkan tekanan darah pada pasien hipertensi dan terapi bekam dapat dijadikan salah satu terapi non farmakologis yang dimasukan pada salah satu pokok bahasan di mata kuliah keperawatan komplementer

Penelitian selanjutnya diharapkan dapat lebih memperhatikan variabel counfounding yang dapat mempengaruhi hasil pengukuran tekanan darah. Penelitian yang akan datang diharapkan dapat mengukur ke efektifitasan waktu berbekam antara kelompok awal, tengah dan akhir bulan dengan analisis multivariat.

\section{DAFTAR PUSTAKA}

Abdullah, M (2016). Fisika Dasar I (edisi revisi). Bandung: Penerbit ITB.

Akbar, N \& Mahati, E. (2013). Pengaruh Bekam Basah terhadap Kolesterol dan tekanan Darah pada Pasien Hipertensi di Semarang. Jurnal Medika Muda: Universitas Diponegoro

Black, J.M., \& Hawks, J.H. (2014). Keperawatan Medikal Bedah: Keperawatan Klinis untuk Hasil yang di Harapkan ( $8^{\text {th }}$ ed). Jakarta: EGC

Fatah, A., A. (2004). Pengobatan dan Penyembuhan menurut Wahyu Nabi. Jakarta: Media Grafika

Fatonah, Rihiantoro \& Astuti. (2015). Pengaruh Terapi Bekam Terhadap Tekanan Darah Penderita Hipertensi. Jurnal Keperawatan. Vol XI

Halimi, A., Hanif, A., \& Albab, U. (2004). Pengobatan dan Penyembuhan menurut Wahyu Nabi. Jakarta: Pustaka As-sabil 
$\mathrm{Hu}, \mathrm{Li}$, Duan, \& Arao. (2013). Prevalenced, purposes, and Preceived Effectiveness of Complementary and Alternative Medicine Use in Hypertension Populasion: A Questionnaire servey. Hindawi Publishing Corporation. ISRN Public Heatlh. Article ID 137472

Irawan \& Ari. (2012). Pengaruh Terapi Bekam Terhadap Penurunan Tekanan Darah pada Klien Hipertensi. Jurnal Ilmu Kesehatan. Vol. 1

Kamaludin. (2010). Pertimbangan dan Alasan Pasien Hipertensi Menjalani Terapi Alternatif Komplementer Bekam di Kabupaten Banyumas. Jurnal Keperawatan Soedirman, Vol. 5 no. 2

Kordafshari, G., Ardakani, Keshaverz, Esfahani, Nazem., Et al. (2017). Cupping Therapy Can Improve the Quality of Life of Healthy People in Tehran. Jounal of Traditional Chines medicine. ISSN 0255-2922

Lestari,Y.A., Hartono, \& A.,Susanti., U. (2017). Pengaruh Bekam Terhadap Perubahan Tekanan Darah pada Penderita Hipertensi di Dusun Tambak Rejo Desa Gayaman Mojokerto. Jurnal Nurse and Health: ISSN: 2088-9909

Potter \& Perry. (2010). Fundamental Keperawatan. Buku 3. Edisi 7. Jakarta: Salemba Medika

Rahmadi, A. (2019). Bekam Tinjauan Hadis dan Medis. Tangerang Selatan: Pustaka pedia

Rahman., M.A. (2016). Pengaruh Terapi Bekam terhadap tekanan Darah pada Pasien Hipertensi di Klinik Bekam Abu Zaky Mubarak. Skripsi: Universitas Islam Negri Syarif Hidayatullah Jakarta

Riskesdas. (2013). Badan Penelitian dan Pengembangan Kesehatan Kementrian Kesehatan RI.

Riskesdas. (2018). Angka Kejadian 10 Penyakit di Indonesia. French retrieved http://www.who.int/about/licensing/\%Cnhttp://apps.who.int/iris/bistream/10665/2 04871/1/9789241565257_eng.pdf

http://www.depkes.go.id/resources/download/infoterkini/materi_rakorpop_2018/H asil\%20Riskesdas\%202018.pdf

Safrianda. (2015). Efektifitas Terapi Bekam Basah Terhadap Perubahan Tekanan Darah Pada Penderita Hipertensi di Rumah Terapi Thibbun Nabawy Pontianak. Universitas Tanjung Pura Pontianak

Schmidt. (2013). Pengaruh Gravitasi pada Tubuh Manusia https://www.dw.com/id/pengaruh-gravitasi-pada-tubuh/a-16947767

Sherwood, L. (2019). Fisiologi Manusia. Dari Sel ke Sistem. Edisi 9. Alih Bahaha: Mandera \& Hartanto. Jakarta: EGC

Thamrin, H. (2012). Perbedaan Tekanan Darah sebelum dan Sesudah Terapi Bekam di Rumah Sehat Afiat CInere tahun 2012. Skripsi: Universitas Islam Negri Syarif Hidayatullah Jakarta

Umar, W. (2012). Bekam untuk 7 Penyakit Kronis. Solo: Thibbia https://www.who.int/cardiovascular_diseases/guidelines/hypertension/en/ diunduh 8 Desember 2018 